\title{
Re-discovering NK cell allo-reactivity in the therapy of solid tumors
}

\author{
Luca Castagna ${ }^{1}$ and Domenico Mavilio ${ }^{2,3^{*}}$ (D)
}

Keywords: NK cells, Allo-reactivity, Adoptive cell therapies, Solid tumors, Lymphomas

Currently, refractory lymphoma or advanced solid tumors have an unfavorable prognosis as conventional therapies are often not curative while providing high levels of toxicity. Indeed, the overall survival of these patients is relatively short with a poor quality of life. This clinical evidence generates a relevant unmet medical need. In the last few years, a renewed interest on adoptive cellular therapies emerged in the field of tumor-immunology due to the remarkable advances in regard to our knowledge of the mechanisms employed by immune system to fight cancer counterbalanced by the pathogenic loops deployed by tumors to escape immune responses. All these gained insights on cancer physiopathology greatly pushed the development of novel technologies in biomedical field that, in turn, led to the discovery of new categories of drugs and alternative therapeutic approaches. Indeed, the use of check-point inhibitors, $\mathrm{T}$ cells with engineered chimeric antigen receptors (CARs) and bi-specific $\mathrm{T}$ cell engagers (BiTE) showed impressive therapeutic potentials in the cure of advanced tumors and are currently being included in the in the armamentarium of clinicians [1].

Among the different approaches of anti-tumor adoptive cell transfer, allogeneic stem cell transplantation (allo-SCT) represents the first and most consolidated form of immunotherapy on the basis of its graft versus tumor (GvT) effect. In this context, immune cell allo-reactivity can be either associated with antigen presentation exerted by class-I major histocompatibility complex (MHC-I) as in the case of CD8 and CD4 T cells or, alternatively, is antigen-independent as occurs with NK cells. However, GvT is counterbalanced by important toxicity and

\footnotetext{
* Correspondence: domenico.mavilio@unimi.it

${ }^{2}$ Department of Medical Biotechnologies and Translational Medicine, University of Milan, Milan, Italy

${ }^{3}$ Unit of Clinical and Experimental Immunology, Humanitas Clinical and Research Center, Rozzano, Milan, Italy

Full list of author information is available at the end of the article
}

non-relapse mortality [2]. Many attempts have been performed, outside the allo-SCT contest, to exploit the allo-reactivity activities of immune cells in order to limit or bypass the toxicity experienced with allo-SCT. In the early 80s' donor lymphocyte infusions (DLI) with allo-activated haplo-identical cells from family members were infused in patients affected by hematological diseases or solid tumors. These study demonstrated that a temporary mixed chimerism and tumor reduction often associated to graft versus host disease (GVHD) is possible [3, 4]. It has been also reported that, after standard chemotherapy, the DLI with G-CSF-primed immune cells from related haplo-identical donors in aged patients affected by acute myeloid leukemia can significantly reduces the rate of tumor relapse [5].

NK cell recognition of "self" to ensure immunologic tolerance versus autologous targets does not require a prior sensitization and relies on large family of inhibitory NK cell receptors (iNKRs) including Killer cell immunoglobulin-like receptors (KIRs) and C-type lectins that recognize specific alleles of MHC-I. The lack of self-MHC-I on tumor-transformed cells makes them susceptible to NK cell mediated lysis via the engagement of several activating NK cell receptors (aNKRs) that bind their ligands expressed on cancer cells (i.e. missing self hypothesis) [6, 7]. Several protocols of adjuvant therapies based on NK cell allo-reactivity have been extensively used in clinics for both hematologic and non-hematologic malignancies either alone or in combination with antibodies and tumor-sensitizing drugs. Indeed, adoptive cell transfer of allogeneic NK cells have been used for the treatment of leukemia, colorectal cancer, hepatocellular cancer, lymphoma and melanoma. The major risk with these procedures is the development of GVHD and several precautions have been put in place to avoid this unfavorable clinical event, such as the 
infusion of CD3 depleted high pure NK cells or the selection of HLA matched donors [8]. Important insights into NK cell function in cancer eradication originated from the knowledge gained from mismatched NK cells in allo-SCT setting, where these innate immune effectors mediate a remarkable graft-versus-leukemia $(\mathrm{GvL})$ effect towards tumor cells of recipient without attacking their normal tissues, thus limiting the onset of GVHD. Moreover, it has been demonstrated HLA-mismatched NK cells in haploidentical allo-SCT improve the overall survival of patients affected by acute myeloid leukemia by controlling tumor relapse without causing GVHD. The reduced priming of alloreactive donor $\mathrm{T}$ cells as a consequence of NK cell killing of recipient antigen-presenting cells and/or of a direct inhibition of activated allo-reactive $\mathrm{T}$ cells have been postulated as explanation of the low frequency of GVHD [9-13]. However, a recent study reported that the infusion of allogeneic IL-15 plus 4-1BBL activated human NK cellbased DLI induced acute GVHD in five out of nine patients affected by solid tumors [14]. Finally, several other variables hampering NK cell allo-reactivity against cancer should be considered. Among these, there are the ability of NK cell to infiltrate the tumor mass via the expression of homing receptors (i.e. chemokines or others) as well as the capacity of cancer cells to impair NK cell effectorfunctions or to became resistant to NK cell lysis (i.e. induction of inhibitory immunologic pathways or lack of expression of aNKR ligands on their surface).

In the paper published by Yang Y. et al. [15] in this issue of Cancer Immunology research, NK cells from random and fully mismatched donors were first selected and expanded to be then infused in patients with either solid tumors $(n=18)$ or lymphomas patients $(n=2)$ in the context of a phase I clinical trial. After testing escalated doses of administered NK cells, authors did not report a maximum tolerated dose (MTD) as only grade 1 and 2 toxicity was observed in the absence of GVHD. The study also shows that the "safe" dose of adoptively transferred NK cells that can be infused up to 3 times at the dose of $3 \times 10^{7}$ cells $/ \mathrm{kg} /$ week. Another important point addressed by this work is the persistence of fully mismatched NK cells in the recipients associated to their anti-tumor effector-functions. Allo-reactive NK cells were detected in the peripheral blood of recipients up to 4 days after infusion with only 8 patients that achieved disease stabilization while 9 progressed. Based on these data, it can be drawn that the lifespan of mismatched NK cells is quite short as they are quickly rejected by recipient immune system. On the other hand, considering the all patients were affected by advanced solid tumors, disease stabilization can be considered an encouraging result likely associated with the infusion of allo-reactive NK cells endowed with great anti-tumor potential. Moreover, as also previously reported [11], Yang Y. et al. postulate that the simultaneous administration of immunosuppressive drugs can prolong the persistence of infused cells and boost the efficacy. Finally, the choice of random healthy donors represents another important information provided by this clinical trial to, at least try, resolve the problem of finding a reliable and effective source of alloreactive NK cells. As reported in haploidentical clinical trials of alloSCT [10], this strategy is aimed to develop a quick and "low cost/low-tech" process to generate clinical grade anticancer NK cells. Indeed, this phase I trial confirm that NK cells from random donors are safe without major toxic effects, thus advocating for larger studies to confirm their clinical efficacy. The exposure to cytokines, viral antigens and haptens is associated with both modulation of NK cell effector function and with the generation of a newly disclosed subset of $\mathrm{CD} 57^{\text {pos }} / \mathrm{NKG} 2 \mathrm{C}^{\text {pos }} / \mathrm{KIR}^{\text {pos }}$ NK cells endowed with adaptive traits $[16,17]$. Hence, further investigation are required to better determine the impact of these "memory-like" NK cells in allo-reactive response against cancer cells occurring in a malignant microenvironment enriched with several immunogenic stimuli such as viruses or cancer-induced haptens or inflammatory soluble factors.

\section{Related article}

Phase I study of random healthy donor-derived allogeneic natural killer cell therapy in patients with malignant lymphoma or advanced solid tumors by Yaewon Yang, Okjae Lim, Tae Min Kim, Yong-Oon Ahn, Hana Choi, Hyejin Chung, Bokyung Min, Jung Hyun Her, Sung Yoo Cho, Bhumsuk Keam, Se-Hoon Lee, Dong-Wan Kim, Yu Kyeong Hwang, and Dae Seog Heo.

\section{Authors' contributions}

LC and DM wrote the editorial and equally contributed to the manuscript. Both authors read and approved the final manuscript.

\section{Competing interests}

The authors declare that they have no competing interests.

\section{Author details}

'Hematology and Bone Marrow, Transplant Unit, Humanitas Cancer Center, Rozzano, Milan, Italy. ${ }^{2}$ Department of Medical Biotechnologies and

Translational Medicine, University of Milan, Milan, Italy. ${ }^{3}$ Unit of Clinical and Experimental Immunology, Humanitas Clinical and Research Center, Rozzano, Milan, Italy.

Received: 21 April 2016 Accepted: 11 August 2016

Published online: 20 September 2016

\section{References}

1. Dhodapkar MV, Dhodapkar KM. Immune modulation in hematologic malignancies. Semin Oncol. 2015;42:617-25.

2. Gooley TA, Chien JW, Pergam SA, Hingorani S, Sorror ML, Boeckh M, Martin PJ, Sandmaier BM, Marr KA, Appelbaum FR, Storb R, McDonald GB. Reduced mortality after allogeneic hematopoietic-cell transplantation. New Engl J Med. 2010;363:2091-101.

3. Kohler PC, Hank JA, Exten R, Minkoff DZ, Wilson DG, Sondel PM. Clinical response of a patient with diffuse histiocytic lymphoma to adoptive chemoimmunotherapy using cyclophosphamide and alloactivated 
haploidentical lymphocytes. A case report and phase I trial. Cancer. 1985;55:552-60.

4. Porter DL, Connors JM, Van Deerlin VMD, Duffy KM, McGarigle C, Saidman SL, Leonard DGB, Antin JH. Graft-versus-tumor induction with donor leukocyte infusions as primary therapy for patients with malignancies. J Clin Oncol. 1999;17:1234-43.

5. Guo M, Hu KX, Liu GX, Yu CL, Qiao JH, Sun QY, Qiao JX, Dong Z, Sun WJ, Sun XD, Zuo HL, Man QH, Liu ZQ, Liu TQ, Zhao HX, Huang YJ, Wei L, Liu B, Wang J, Shen XL, Ai HS. HLA-mismatched stem-cell microtransplantation as postremission therapy for acute myeloid leukemia: long-term follow-up. J Clin Oncol. 2012;30:4084-90.

6. Ljunggren $\mathrm{HG}$, Karre K. In search of the 'missing self': MHC molecules and NK cell recognition. Immunol Today. 1990;11:237-44.

7. Hudspeth $\mathrm{K}$, Donadon $\mathrm{M}$, Cimino $\mathrm{M}$, Pontarini $\mathrm{E}$, Tentorio $\mathrm{P}$, Preti $\mathrm{M}$, Hong M, Bertoletti A, Bicciato S, Invernizzi P, Lugli E, Torzilli G, Gershwin ME, Mavilio D. Human liver-resident CD56(bright)/CD16(neg) NK cells are retained within hepatic sinusoids via the engagement of CCR5 and CXCR6 pathways. J Autoimmun. 2016;66:40-50.

8. Dahlberg Cl, Sarhan D, Chrobok M, Duru AD, Alici E. Natural killer cell-based therapies targeting cancer: possible strategies to gain and sustain anti-tumor activity. Front Immunol. 2015;6:605.

9. Ruggeri L, Capanni M, Urbani E, Perruccio K, Shlomchik WD, Tosti A, Posati S, Rogaia D, Frassoni F, Aversa F, Martelli MF, Velardi A. Effectiveness of donor natural killer cell alloreactivity in mismatched hematopoietic transplants. Science. 2002;295:2097-100.

10. Curti A, Ruggeri L, D'Addio A, Bontadini A, Dan E, Motta MR, Trabanelli S, Giudice V, Urbani E, Martinelli G, Paolini S, Fruet F, Isidori A, Parisi S, Bandini G, Baccarani M, Velardi A, Lemoli RM. Successful transfer of alloreactive haploidentical KIR ligand-mismatched natural killer cells after infusion in elderly high risk acute myeloid leukemia patients. Blood. 2011;118:3273-9.

11. Miller JS, Soignier Y, Panoskaltsis-Mortari A, McNearney SA, Yun GH, Fautsch SK, McKenna D, Le C, Defor TE, Burns LJ, Orchard PJ, Blazar BR, Wagner JE, Slungaard A, Weisdorf DJ, Okazaki IJ, McGlave PB. Successful adoptive transfer and in vivo expansion of human haploidentical NK cells in patients with cancer. Blood. 2005;105:3051-7.

12. Leung $\mathbf{W}$. Infusions of allogeneic natural killer cells as cancer therapy. Clin Cancer Res. 2014;20:3390-400.

13. Olson JA, Leveson-Gower DB, Gill S, Baker J, Beilhack A, Negrin RS. NK cells mediate reduction of GVHD by inhibiting activated, alloreactive T cells while retaining GVT effects. Blood. 2010;115:4293-301.

14. Shah NN, Baird K, Delbrook CP, Fleisher TA, Kohler ME, Rampertaap S, Lemberg K, Hurley CK, Kleiner DE, Merchant MS, Pittaluga S, Sabatino M, Stroncek DF, Wayne AS, Zhang H, Fry TJ, Mackall CL. Acute GVHD in patients receiving IL-15/4-1BBL activated NK cells following T-cell-depleted stem cell transplantation. Blood. 2015:125:784-92.

15. Yang Y, Lim O, Kim TM, Ahn YO, Choi H, Chung H, Min B, Her JH, Cho SY, Keam B, Lee SH, Kim DW, Hwang YK, Heo DS. Phase I study of random healthy donor-derived allogeneic natural killer cell therapy in patients with malignant lymphoma or advanced solid tumors. Cancer Immunol Res. 2016. In press.

16. Varchetta S, Oliviero B, Mavilio D, Mondelli MU. Different combinations of cytokines and activating receptor stimuli are required for human natural killer cell functional diversity. Cytokine. 2013;62:58-63.

17. Lugli E, Hudspeth K, Roberto A, Mavilio D. Tissue-resident and memory properties of human T-cell and NK-cell subsets. Eur J Immunol. 2016:46(8):1809-17.

\section{Submit your next manuscript to BioMed Central and we will help you at every step:}

- We accept pre-submission inquiries

- Our selector tool helps you to find the most relevant journal

- We provide round the clock customer support

- Convenient online submission

- Thorough peer review

- Inclusion in PubMed and all major indexing services

- Maximum visibility for your research

Submit your manuscript at www.biomedcentral.com/submit
Biomed Central 